\title{
Isolation, identification, pathogenicity test and screening of brinjal cultivars against damping off in brinjal
}

\author{
V.M. GHOLVE*, V.R. TATIKUNDALWAR AND S.S. WAGH
}

Department of Plant Pathology, Vasantrao Naik Marathwada Krishi Vidyapeeth, PARBHANI (M.S.) INDIA

\section{ARITCLE INFO}

Received : 02.12 .2014

Accepted : 14.03.2016

KEY WORDS :

Brinjal, Isolation, Pathogenicity, In vitro, Screening, Pythium ultimum
*Corresponding author:

Email: vikramgholve@ rediffmail.com

\begin{abstract}
Brinjal or egg plant (Solanum melongena $\mathrm{L}$.) is widely grown vegetable crop in India. Of the various diseases affecting brinjal, damping off caused by Pythium ultimum Trow. is one of the most destructive diseases causing several yield losses. The pathogen (P.ultimum) from naturally diseased brinjal plant showing typical symptoms of damping off was successfully isolated on the basal culture medium potato dextrose agar. The fungus P.ultimum produce nonseptate, well branched, colourless to whitish mycelium, sporangia on indeterminate sporangiophores when observed under the microscope. Pathogenicity of Pythium ultimum Trow. was proved by sick soil method in pot culture, sowing brinjal cv. HADGAON LOCAL under screen house condition. The pathogen was reisolated on PDA from artificially diseased brinjal seedling, and compared its cultural and morphological characteristics with the original fungus isolated from the naturally damping off diseased brinjal plant. Based on the typical symptoms of damping off, morphological and cultural characteristics, microscopic observations and pathogenicity test; the test pathogen was identified and confirmed as P. ultimum. Results revealed that of 13 brinjal cultivar lines, five lines viz., EPM-564, Ajay, Kranti seed, Brinjal MG and Puneri Kateri were moderately susceptible with disease incidence in the range of 11.10 to 16.66 per cent and five lines viz., Vishal, Arnav, Local Pingali, Local Kinwat, Local Hadgaon were susceptible with the disease incidence of about 22.21 to 44.44 per cent.
\end{abstract}

How to view point the article : Gholve, V.M., Tatikundalwar, V.R. and Wagh, S.S (2016). Isolation, identification, pathogenicity test and screening of brinjal cultivars against damping off in brinjal. Internat. J. Plant Protec., 9(1) : 246-251. 